\title{
Synthesis of Silicon-Carbon by Polyaniline Coating and Electrochemical Properties of the Si-C|Li Cell
}

\author{
Chil-Hoon Doh, ${ }^{*}$ Seong Il Kim, Ki-Young Jeong, Bong-Soo Jin, Kay Hyeok An, \\ Byung Chul Min. ${ }^{+}$Seong-In Moon, and Mun-Soo Yun \\ Korea Electrotechnology Research Instifute, Changwon, Gyeongnam 641-120, Korea. "E-mail: chdoh@keri.re.kr \\ "BK21 Physics Div., Sungknninkwan University, Suwon 440-746, Korea \\ "Dept. Enwiromental Chem., Changwon College of Korea Polvtechnic VI, Changwon 641-772, Korea \\ Received September \&, 2005
}

\begin{abstract}
Si-C composites were prepared by the carbonization of polyaniline (PAn) coated on silicone powder. The physical and electrochemical properties of the $\mathrm{Si}-\mathrm{C}$ composites were characterized by particle-size analysis, $\mathrm{X}$ ray diffraction, scanning electron microscopy, and battery electrochemical tests. The average particle size of $\$ \mathrm{i}$ was increased by the coating of Pan but somewhat reduced by the carbonization to give silicone-carbon composites. The co-existence of crystalline silicone and amorphous-like carbon was confirmed by XRD analyses. SEM photos showed that the silicone particles were well covered with carbonaceous materials, depending on the PAn content. Si-ClLi cells were fabricated using the $\mathrm{Si}-\mathrm{C}$ composites and tested using galvanostatic charge-discharge. Si-C|Li cells gave better electrochemical properties than SilLi cells. Si-C|Li cells using $\mathrm{Si}-\mathrm{C}$ from $\mathrm{IICl}-$ undoped precursor $\mathrm{P} \Lambda \mathrm{n}$ showed better electrochemical properties than precursor $\mathrm{P} A \mathrm{n}$ doped in $\mathrm{IICl}$. The addition of an electrolyte containing 4-fluoroethylene carbonate (FEC) increased the initial discharge capacity. $\Lambda \mathrm{lso}$, another electrochemical test, the galvanostatic charge-discharge test with GISOC (gradual increasing of the state of charge) was carried out. Si-C(Si:P $A \mathrm{n}=50: 50$ wt. ratio) Li cell showed $414 \mathrm{~m} / \mathrm{h} / \mathrm{g}$ of reversible specific capacity, $75.7 \%$ of IIE (initial intercalation efficiency), $35.4 \mathrm{~m} / \mathrm{h} / \mathrm{g}$ of IICs (surface irreversible specific capacity).
\end{abstract}

Key Words : Lithium battery, Anode, Silicon, Carbon

\section{Introduction}

Recent technical advances in information electronic devices have made them more portable, compact and lightweight without surrendering performance and multimedia functionality. The power source of these portable devices requires a high-performance secondary battery. In the early 1990 s, the Li secondary battery was adopted as a power source for many of these devices. As consumers demand ever higher standards of performance from their personal electronics products, researchers around the world are engaged in a massive effort to increase battery efficiency. ${ }^{1-5}$ One focus of interest is anode materials based on silicone, which has the theoretical specific capacity of $4200 \mathrm{mAh} / \mathrm{g}$ with a density of $2.33 \mathrm{~g} / \mathrm{cm}^{3}$. In comparison, graphite has a specific capacity of $372 \mathrm{mAh} / \mathrm{g}$. The intercalation potential of silicone is similar to that of graphite. The major disadvantages of silicone, in this case, are low electronic conductivity at the semi-conductor level $\left(\sim 10^{-4} \mathrm{~S} / \mathrm{cm}\right)$ and a volume expansion of $297 \%\left(\mathrm{Li}_{2} / \mathrm{Si}_{5}\right)$ during $\mathrm{Li}$ alloying/dealloying to lead fast capacity fade ${ }^{6-12}$

In the present study, carbon coated silicone (Si-C) was prepared by the carbonization of polyaniline (PAn) coated silicone. Carbon in the carbon-coated silicone encapsulates the silicone particles in the sponge-like foam. The carbon foam may mitigate the volume expansion of silicone particles during $\mathrm{Li}$ alloying/dealloying, provide an electronic conduction path, and provide an ion conduction path through the void. The electrochemical properties of $\mathrm{Si}-\mathrm{C}$ materials were analyzed by the galvanostatic charge-discharge test using a $\mathrm{Si}-\mathrm{C} \mid \mathrm{Li}$ coin cell with electrolytes, with/without fluoro ethylene carbonate (FEC) additive. Cut-off limits were controlled by the potential range and (GISOC). ${ }^{10-12}$ Using GISOC results, we determined IIE (the initial intercalation efficiency) for lithium intercalation reversibility, IIC (the initial irreversible capacity by the surface) for the irreversibility between electrode-electrolyte, and the reversible intercalation range. All were evaluated as the typical electrode performance for the given electrode-electrolyte system.

\section{Experimental Section}

Preparation Si-C Composites. Si-C, the anode candidate material, was prepared from $\mathrm{Si}$ powder and polyaniline (PAn). Aniline $\left(\mathrm{C}_{6} \mathrm{H}_{7} \mathrm{~N}\right)$, from Aldrich of the U.S.A, in HCl$\mathrm{H}_{2} \mathrm{SO}_{4}$ aqueous solution containing $2-5 \mu \mathrm{m} \mathrm{Si}$ powder (Atlantic Equipment Engineers, U.S.A) was oxidatively polymerized by the slow dropping of an oxidant solution of ammonium persulfate $\left.\left(\mathrm{NH}_{4}\right)_{2} \mathrm{~S}_{2} \mathrm{O}_{4}\right)$ at a vessel temperature of $-5 \sim 0{ }^{\circ} \mathrm{C}$. Obtained solid material was washed with water and acetone, dried at $100^{\circ} \mathrm{C}$ for 24 hours, and subjected to carbonization $\left(1000^{\circ} \mathrm{C}, 2 \mathrm{hrs}\right.$, argon atomosphere) to give $\mathrm{Si}-\mathrm{C}$ material. Two kinds of $\mathrm{Si}-\mathrm{C}$ composite materials were prepared based on a $70: 30$ and $50: 50$ weight ratio for Si:PAn. HCl undoped Si-PAn material $(70: 30$ weight ratio) 
undoped by an ammonia solution $\left(28 \% \mathrm{NH}_{4} \mathrm{OH}\right)$ was also carbonized by the identical method.

Structural and Morphological Characterization. Structural characterization was done by powder X-Ray technique on a Philips $1830 \mathrm{X}$-Ray diffractometer using $\mathrm{Ni}$ filtered $\mathrm{Cu}$ $\mathrm{K}$ radiation $(=1.5406)$ in the $2 \theta$ range of $5^{\circ} \sim 120^{\circ}$ at a scan rate of $0.04 \% \mathrm{sec}$. The surface morphology of the particles was examined through FE-SEM images obtained with a Hitachi s-4800 Field Emission Scanning Electron Microscope (FE-SEM). The actual size of the particles was measured using a Malvem easy particle size analyzer (Masterizer, 0.3 $\mathrm{m}$ to $300 \mathrm{~m}$, Malvern of the UK). The thernal characteristics of the polyaniline were analyzed using a DSC-TGA(SDT Q600 thermal analyzer from TA Instruments of the U.S.A.).

Electrochemical Characterization. Electrochemical properties were evaluated by fabricating 2032-type coin cells. The electrode slurries were made by dispersing $92 \mathrm{wt} . \%$ of active material, 4 wt. $\%$ of $\mathrm{CMC}$ (carboxymethyl cellulose $1.2 \mathrm{wt} \%$ solution in water) binder, and $4 \mathrm{wt} \%$ of SBR (styrene butadiene rubber $40 \mathrm{wt} \%$ solution in water). The resulting slurries were coated on copper foil and dried for 30 minutes at $110^{\circ} \mathrm{C}$ to remove solvent. (The coated slurries were pressed into a sheets to $70 \%$ rate: Editor's note: The preceding is rewritten as follows:) The slurry-coated foil was pressed with a twin roll calender, resulting in sheets that were $70 \%$ of their original thickness. The foil was then dried under vacuum at $60^{\circ} \mathrm{C}$ for 24 hours to give the apparent density of $1.501 .6 \mathrm{~g} / \mathrm{cm}^{3}$.

Coin cells were constructed with $\mathrm{Li}$ metal as the counter electrode and the coated electrode as the anode (working electrode). The electrolyte solution for the cell was $1.0 \mathrm{M}$ $\mathrm{LiPF}_{6}$ in $\mathrm{EC} / \mathrm{DMC} / \mathrm{EMC} / \mathrm{PC}$ in the ratio of $4: 3: 3: 1 \mathrm{vol} . \%$ (Cheil Industries Ltd, Korea) with/without 4-fluoroethylene carbonate (FEC, 5 wt.\%; Ulsan Chemical Co., Ltd., Korea). The constructed cells were aged for 24 hours at ambient temperature. The galvanostatic charge-discharge test was carried out at $\mathrm{C} / 10$ hour rate. Discharge limits were controlled by the potential of $0 \mathrm{~V}$ and by the specific capacity, adopting the gradual increasing of state of charge (GISOC) test method. ${ }^{10-12}$ Charge potential limits were $3 \mathrm{~V}$. For comparison, a $\mathrm{Si} \mid \mathrm{Li}$ cell was constructed using the $\mathrm{Si}$ active material, as in the identical procedure mentioned above, and the cell was subjected to cycle test, using the identical condition as mentioned above.

\section{Results and Discussion}

Particle Size Analyses. The average particle size distribution of Si-C material was about $10 \mu \mathrm{m}$, an increase from 1.2 $\mu \mathrm{m}$, the average value of the starting $\mathrm{Si}$ powder. $\mathrm{HCl}$ undoped and doped Si-PAn material as a precursor of Si-C had an average particle size of $10 \mu \mathrm{m}$ and $10 \mu \mathrm{m}$, respectively.

Figure 1 shows the change in the average particle size during the preparation of $\mathrm{Si}-\mathrm{C}$ material through the $\mathrm{Si}: \mathrm{Pan}$ ( $70: 30$ wt. ratio) precursor. Average particle size was increased by the coating of polyaniline and decreased by the shrinkage during the carbonization.

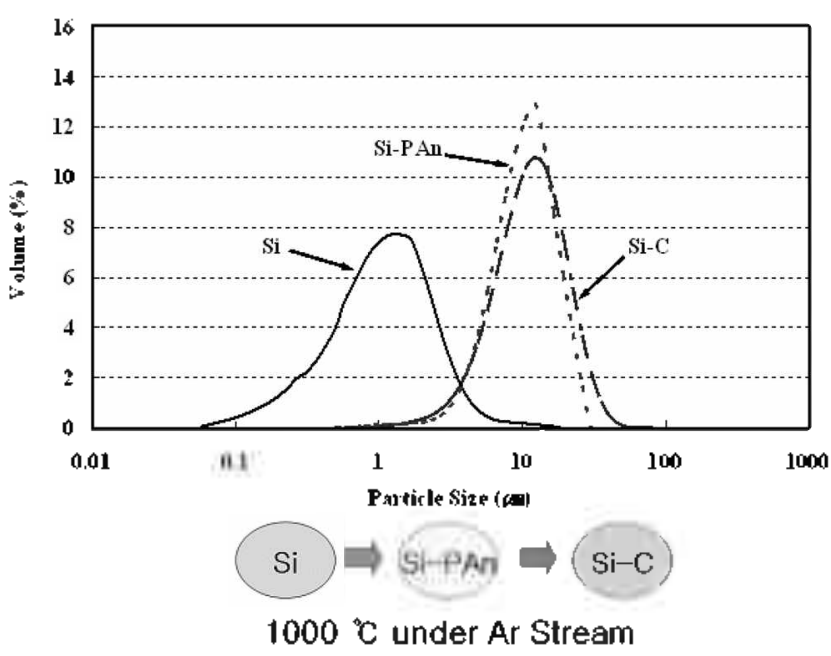

Figure 1. Change of particle size distribution during carbon coating to silicone powder.

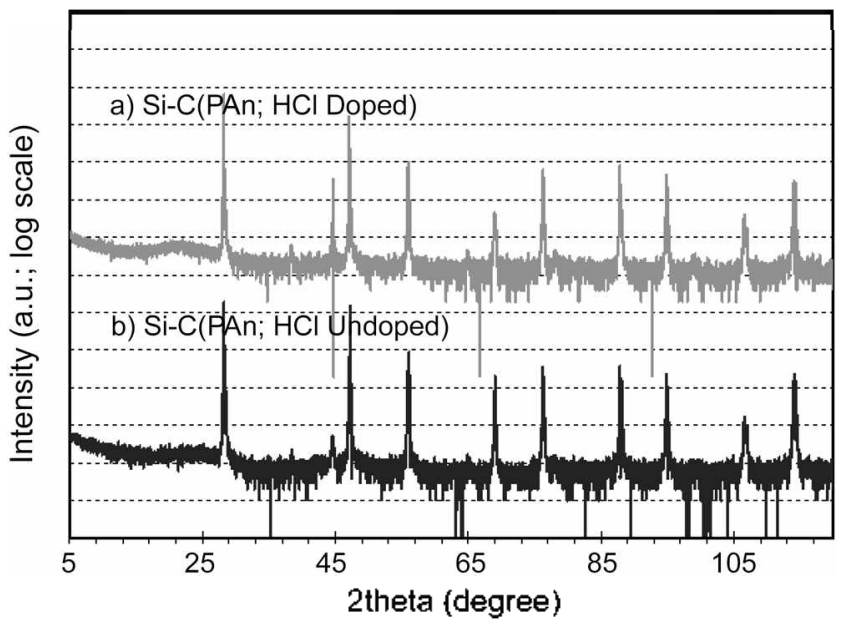

Figure 2. XRD patterns exhibited by $\mathrm{Si}-\mathrm{C}$ inaterials from the precusor of Si:PAn (70:30 wt. ratio).

Structural Results-PXRD Studies. Figure 2 shows the XRD pattenns of the carbon coated silicon powder in logarithmic scale. The presence of a peak is easily identified due to silicon. The existence of amorphous carbon is recognized at a $2 \theta$ value of $23^{\circ}$. Carbon with low crystallinity was found in the form of co-existence with silicon. The average layer spacing for $\mathrm{d}_{002}$ was calculated as approximately $3.864 \AA$. The calculated degree of graphitization was found to be nearly amorphous. ${ }^{13} \mathrm{Si}-\mathrm{C}$ from $\mathrm{HCl}$ doped and undoped $\mathrm{PAn}$ precursor showed similar amorphous structure but slightly different distribution of $\mathrm{d}_{0 \times 2}$ bands.

Morphological Results-SEM. Figure 3 shows the SEM image of the carbon-coated silicon material in the increasing order of PAn content. $\mathrm{HCl}$ doped and undoped Si-PAn gave similar Si-C materials, as shown in Figure $3 \mathrm{~b}$ and Figure $3 \mathrm{c}$. The carbon content increased proportional to the total amount of PAn polymerized by comparison in Figure 3 .

Electrochemical Characterization Results. Electrochemical characterization of 2032 type coin cells, using the 


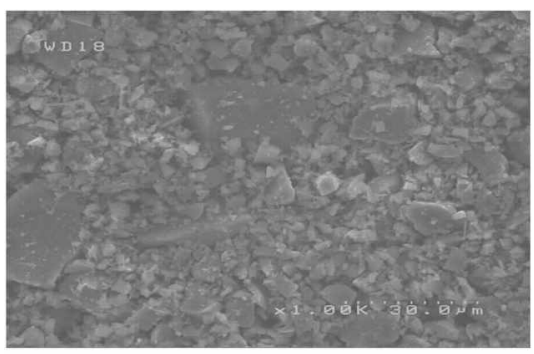

(a) X 1000; Si only

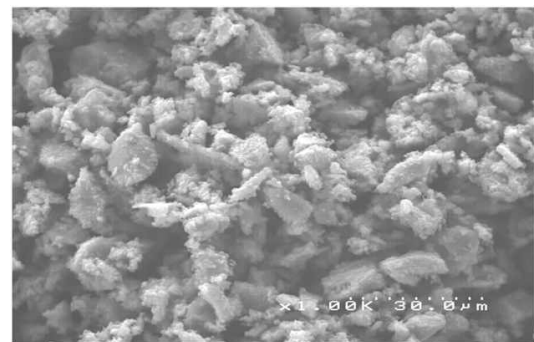

(b) $\times 1000$; Si : PAn = $70: 30$ wt. $\%$ (doping)

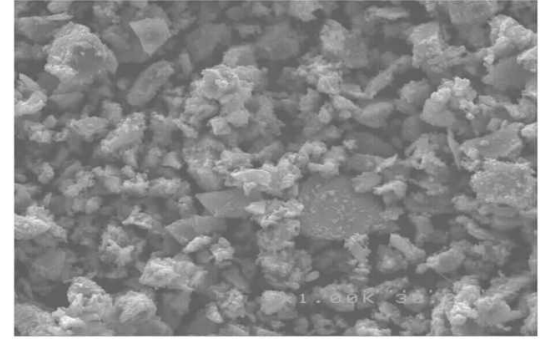

(c) $\times 1000 ;$ Si : PAn $=70: 30$ wt. $\%$ (undoping)

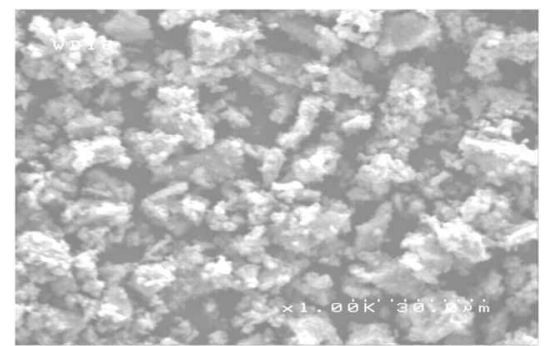

(d) $\times 1000 ; \mathrm{Si}: \mathrm{PAn}=50: 50$ wt. $\%$

Figure 3. SEM inages of $\mathrm{Si}$ and $\mathrm{Si}-\mathrm{C}$ materials.

coated electrode as the working electrode and the lithium metal as the counter electrode, was carried out by the galvanostatic method using a cycle test and GISOC test.

The constructed coin cells were subjected to the charge/ discharge test for 20 cycles with a current of $\mathrm{C} / 10$ hour rate and at a potential range of $0-3 \mathrm{~V}$. The specific capacity and the potential behavior of $\mathrm{Si}-\mathrm{C} \mid \mathrm{Li}$ cells were plotted as the function of cycle number and specific capacity, as shown in Figure 4.

A SilLi cell in Fig. 4a showed only $0.5 \mathrm{mAh} / \mathrm{g}$ for the first specific charge capacity. Si-C(Si:PAn $=70: 30 \mathrm{wt} . \%) \mid \mathbf{L i}$ cells showed $1410 \mathrm{mAh} / \mathrm{g}$ for the first discharge capacity and 124 $\mathrm{mAh} / \mathrm{g}$ for the first charge capacity for HCl-doped PAn precursor, as seen in Figure $4 \mathrm{~b}$, and $1337 \mathrm{mAh} / \mathrm{g}$ for the first discharge capacity and $371 \mathrm{mAh} / \mathrm{g}$ for the first charge capacity for $\mathrm{HCl}$ undoped PAn precursor as seen in Figure $4 c$. Different electrochemical characteristics were found in two $\mathrm{Si}-\mathrm{C}(\mathrm{Si}: \mathrm{PAn}=70: 30 \mathrm{wt} . \%) \mid \mathrm{Li}$ cells, varying from the HCl-doped and undoped PAn precursors. The difference might haveoriginated with the formation of carbon material between the amine type and ammonium-salt type precursors of polyaniline. DSC-TGA analyses of $\mathrm{HCl}$-doped and undoped PAn were performed, as shown in Figure 5, and compared. The endothermic DSC peaks of HCl-doped PAn appear at $98{ }^{\circ} \mathrm{C}$ and $246{ }^{\circ} \mathrm{C}$, with the full width of half maximum (FWHM) at $64{ }^{\circ} \mathrm{C}$ and $70^{\circ} \mathrm{C}$, respectively. The endothermic heat values were $569 \mathrm{~J} / \mathrm{g}$ and $50 \mathrm{~J} / \mathrm{g}$ for the peaks of $98^{\circ} \mathrm{C}$ and $246^{\circ} \mathrm{C}$, respectively. The weight was based on the loaded polyaniline. Another endothermic peak appeared at $958^{\circ} \mathrm{C}$ with a FWHM of $176^{\circ} \mathrm{C}$ and an endothermic heat value of $1039 \mathrm{~J} / \mathrm{g}$. Total endothermic heat in the range of $25-1200^{\circ} \mathrm{C}$ was $1089 \mathrm{~J} / \mathrm{g}$. TGA analysis showed a weight loss of $49 \%$ through $200^{\circ} \mathrm{C}$, corresponding to the first endothermic route, followed by an additional $11 \%$ loss from $200^{\circ} \mathrm{C}$ to $400{ }^{\circ} \mathrm{C}$. Further weight loss of $16 \%$ was observed at $700^{\circ} \mathrm{C}$ without endothermic peaks. Total weight loss was $81 \%$ through $1200^{\circ} \mathrm{C}$. The endothemic DSC peaks of $\mathrm{HCl}$-undoped PAn appeared at $63{ }^{\circ} \mathrm{C}$, with an endothermic heat of $52 \mathrm{~J} / \mathrm{g}$, which was smaller than that of $\mathrm{HCl}-$ doped PAn. These DSC-TGA results show that the first endothermic peak of $\mathrm{HCl}$-doped PAn resulted from the desorption of $\mathrm{HCl}$. Another endothemic peak appeared at $1031^{\circ} \mathrm{C}$ with a FWHM of $64^{\circ} \mathrm{C}$ and an endothermic heat value of $113 \mathrm{~J} / \mathrm{g}$. Total endothermic heat in the range of $25-$ $1200^{\circ} \mathrm{C}$ was found to be $472 \mathrm{~J} / \mathrm{g}$. TGA analysis showed a small weight loss of $2.5 \%$ through $400{ }^{\circ} \mathrm{C}$. Additional weight loss of $35.5 \%$ was observed through $700^{\circ} \mathrm{C}$ without endothermic peaks. Total weight loss was $53 \%$ through 1200 ${ }^{\circ} \mathrm{C}$. The formula weight of PAn. $\mathrm{HCl}$ and PAn are $127.5 \mathrm{~g}$ and $91 \mathrm{~g} /$ formula, respectively. In case of PAn $\mathrm{HCl}$, the intial weight loss of $49 \%$ seems due to the desorption of $\mathrm{HCl}$ and $\mathrm{H}_{2} \mathrm{O}$. The water content of $\mathrm{PAn} \cdot \mathrm{HCl}$ was calculated as three molecules per PAn unit from the weight loss value.

The charge-discharge characteristics of $\mathrm{Si}-\mathrm{C} \mid \mathrm{Li}$ cell, Si-C material from the $\mathrm{HCl}$ doped $\mathrm{PAn}$ presursor and $\mathrm{Si}$ powder (50:50 weight ratio), as shown in Figure $4 \mathrm{~d}$ showed high capacity compared with that of $\mathrm{Si}-\mathrm{C}$ material from PAn and Si $(30: 70$ weight ratio). The first discharge and charge capacities were $1950 \mathrm{mAh} / \mathrm{g}$ and $205 \mathrm{mAh} / \mathrm{g}$, respectively.

Using the electrolyte containing FEC additives, chargedischarge characteristics are presented in Figure 6. Si$\mathrm{C}(\mathrm{Si}: \mathrm{PAn}=70: 30 \mathrm{wt} \%) \mid \mathrm{Li}$ cells showed $1759 \mathrm{mAh} / \mathrm{g}$ of the first discharge capacity and $127 \mathrm{mAh} / \mathrm{g}$ of the first charge capacity for HCl-doped PAn precursor, as shown Figure 6a, and $2057 \mathrm{mAh} / \mathrm{g}$ of the first discharge capacity and 224 $\mathrm{mAh} / \mathrm{g}$ of the first charge capacity for $\mathrm{HCl}$-undoped PAn precursor, as shown Figure $6 \mathrm{~b}$. The adoption of FEC to electrolyte increased the initial discharge capacity, compared 

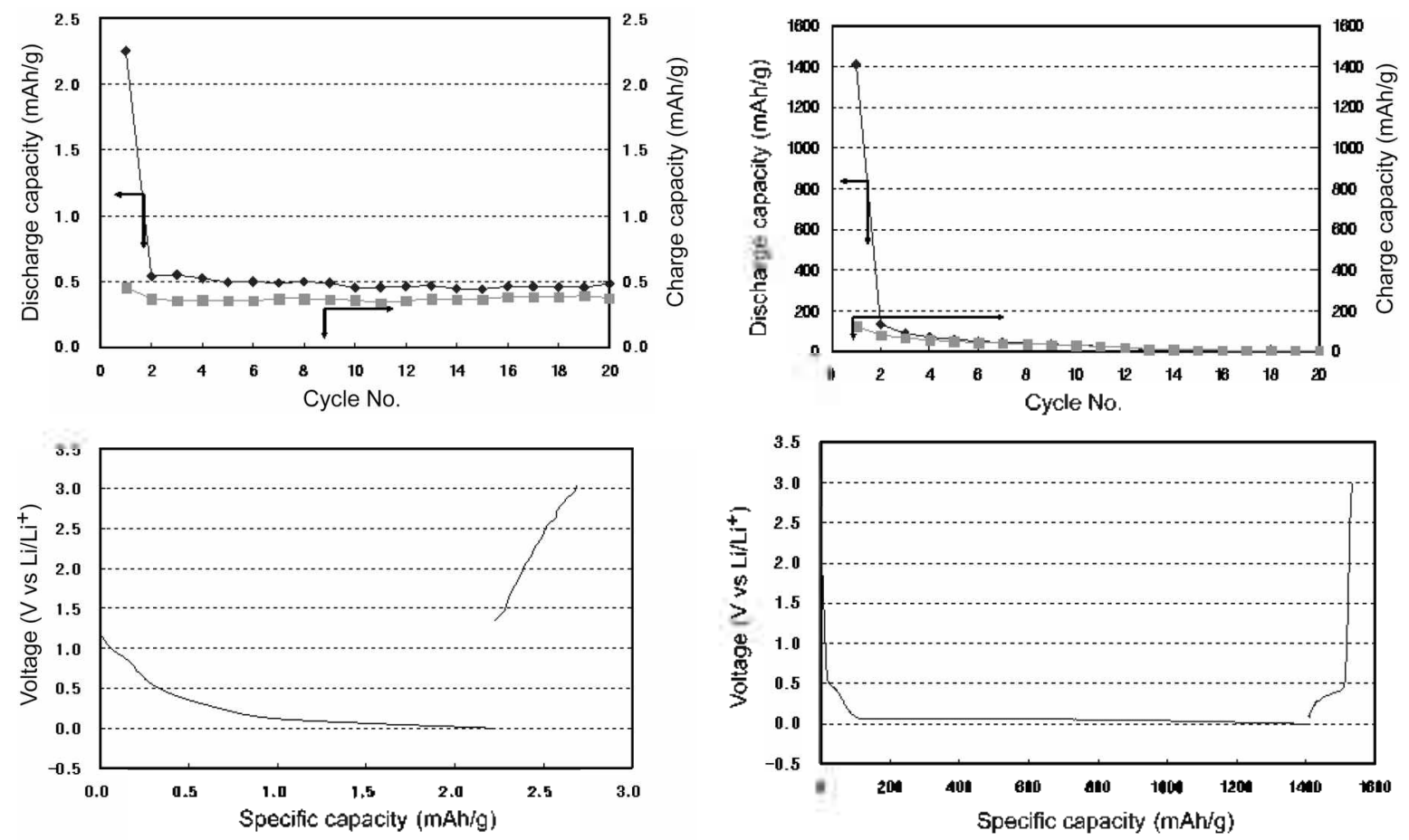

(a) Si (Si:PAn = 100:0 wt.\%)

(b) Si-C (Si:PAn $(\mathrm{HCl}$ undoping $)=70: 30 \mathrm{wt} \%$ )
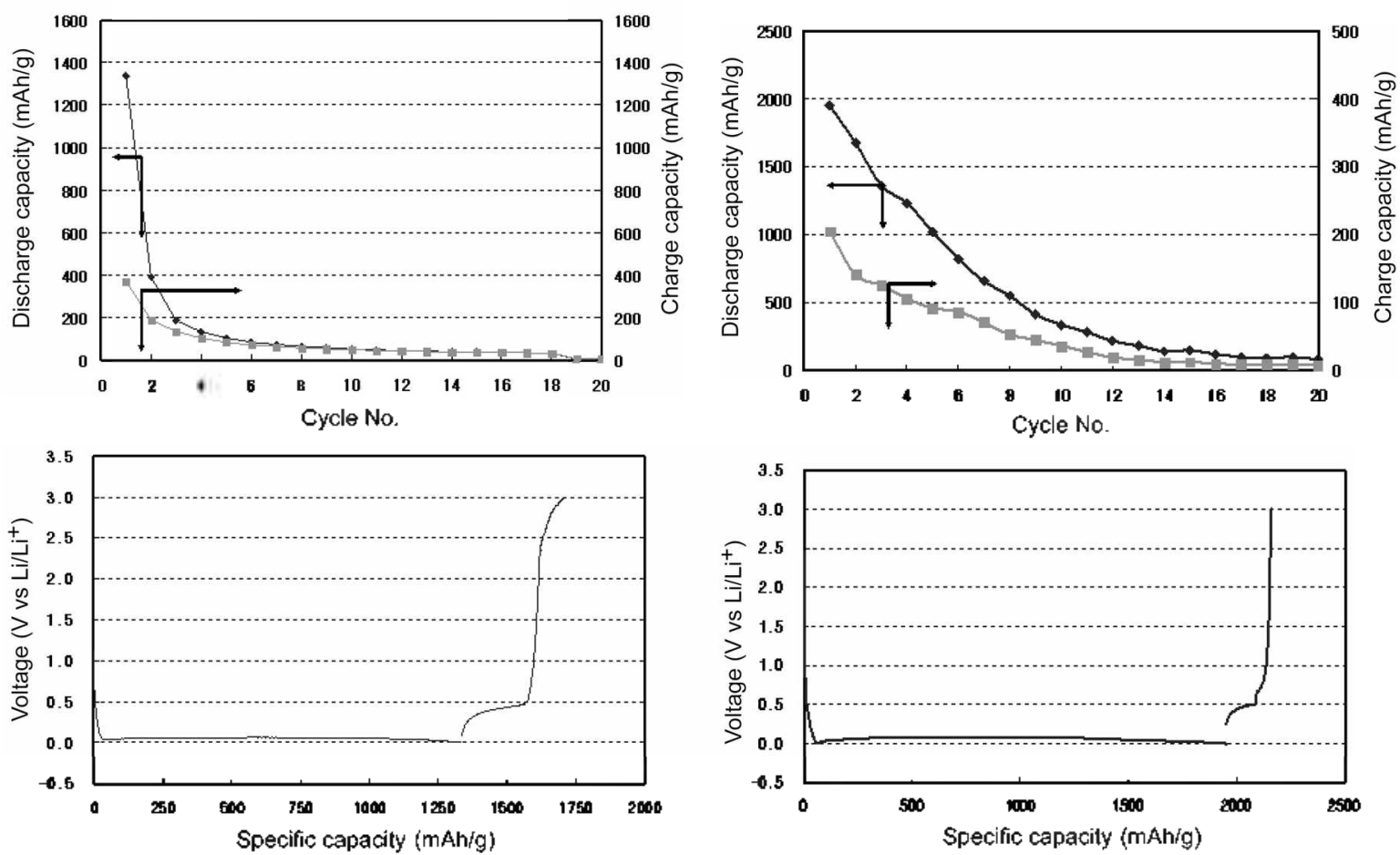

(c) Si-C (Si:PAn $(\mathrm{HCl}$ undoping) $=70: 30$ wt.\%)

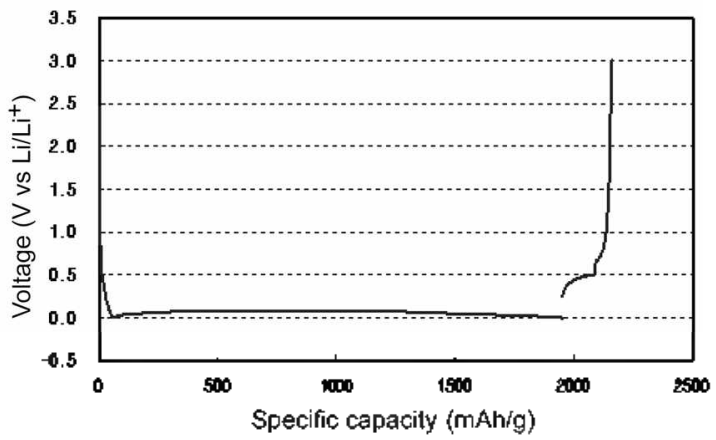

(d) Si-C (Si:PAn $(\mathrm{HCl}$ doping $)=50: 50$ wt. \%)

Figure 4. Specific capacity and cycleability behavior of $\mathrm{Si}[\mathrm{Li}$ and $\mathrm{Si}-\mathrm{C}|1 \mathrm{M} \mathrm{LiPF} / \mathrm{EC}+\mathrm{EMC}+\mathrm{DMC}+\mathrm{PC}=4: 3: 3: 1| \mathrm{Li}$ cells.

with the case of electrolyte without FEC, as shown Figure $4 \mathrm{~b}$ and Figure 4c.

The irreversible capacity of Si-C(Si:PAn $=50: 50$ wt. ratio) $[\mathrm{Li}$ cell has been plotted against the specific discharge capacityas the results of the GISOC test in Figure 7. Analytical results of the GISOC test for various cells are summarized in Table 1 . The reversible range of the specific capacity of $\mathrm{Si} \mid \mathrm{Li}, \mathrm{Si}-\mathrm{C}(\mathrm{Si}: \mathrm{PAn}=70: 30 \mathrm{wt}$. ratio $) \mid \mathrm{Li}$, and Si$\mathrm{C}(\mathrm{Si}: \mathrm{PA} n=50: 50$ wt. ratio) $\mid \mathrm{Li}$ cells with the electrolyte without $\mathrm{FEC}$ additive were $c a .49, c a .150$, and $c a .414$ $\mathrm{mAh} / \mathrm{g}$, respectively. For these reversible ranges, the initial intercalation efficiencies, IIE, were $27.8,55.1$ and $75.7 \%$, and the surface irreversible capacities were $49.3,46.6$ and $35.4 \mathrm{mAh} / \mathrm{g}$, respectively. 


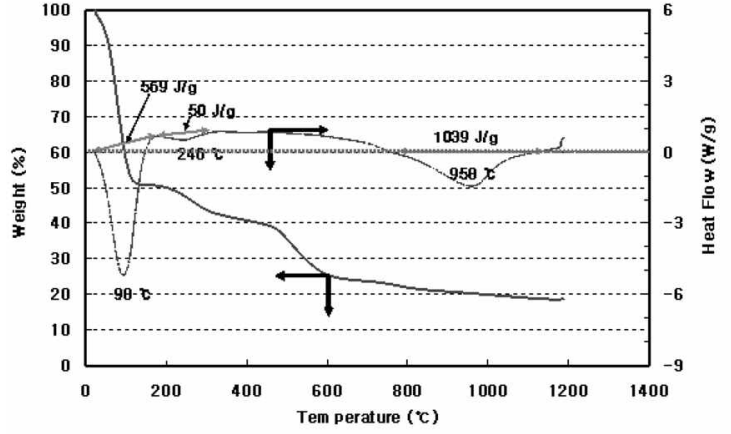

(a) $\mathrm{HCl}$ doped polyaniline (PAn)

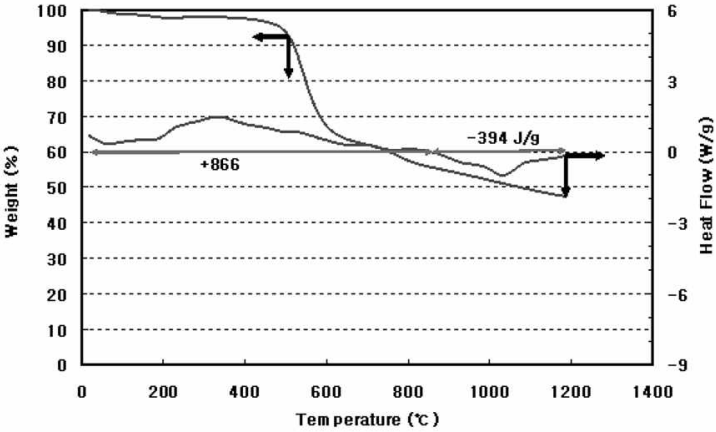

(b) $\mathrm{HCl}$ undoped polyaniline (PAn)

Figure 5. TGA-DSC analyses of $\mathrm{HCl}$ doped/undoped polyaniline ( $\mathrm{PAn}$ ).
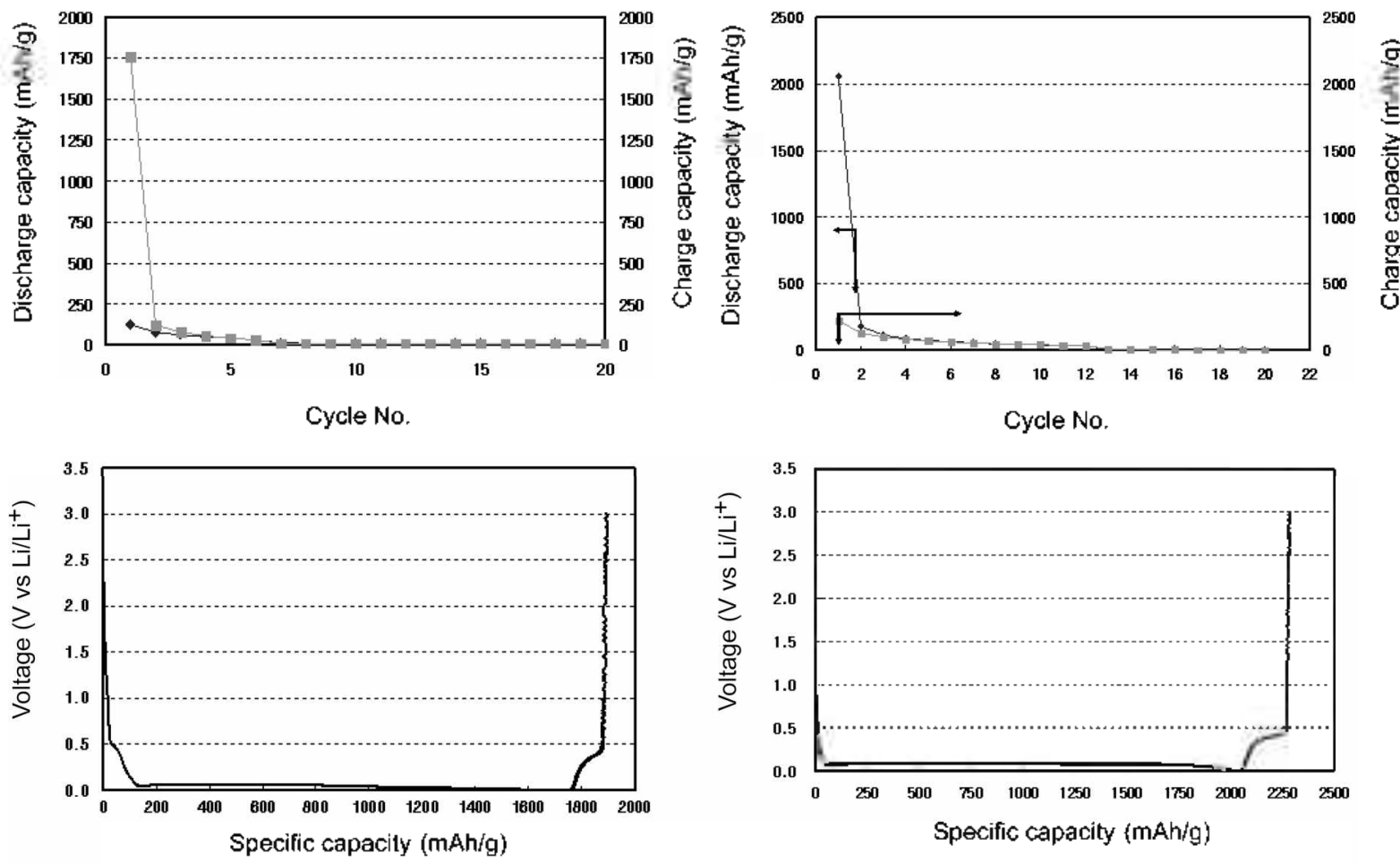

(a) Si-C (Si:PAn $(\mathrm{HCl}$ doping $)=70: 30$ wt. $\%$ )

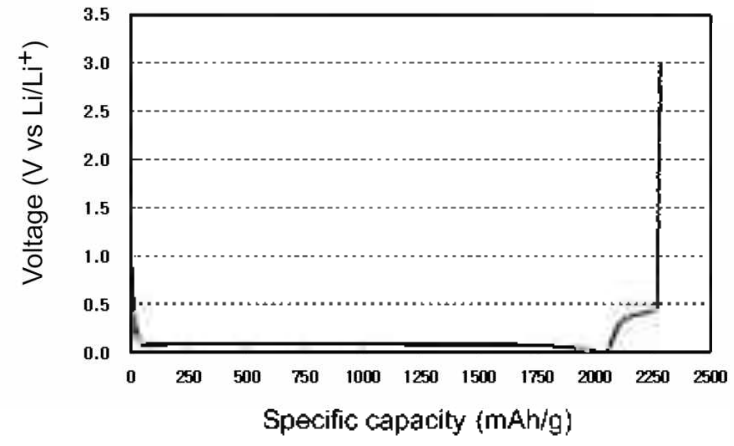

(b) $\mathrm{SiC}$ (Si:PAn $(\mathrm{HCl}$ undoping $)=70: 30 \mathrm{wt} . \%$ )

Figure 6. Specific capacity and cycleability of $\mathrm{Si}-\mathrm{C} \mid 1 \mathrm{M} \mathrm{LiPF} 6 / \mathrm{LC}+\mathrm{EMC}+\mathrm{DMC}+\mathrm{PC}=4: 3: 3: 1$ with $\mathrm{FEC} \mid \mathrm{Li}$ cell.

$\mathrm{Si}-\mathrm{C}$ materials from Si:Pan $(70: 30 \mathrm{w} / \mathrm{w})$ had low carbon content compared with that of Si:Pan $(50: 50 \mathrm{w} / \mathrm{w})$. The degradation of the electronic conduction pathway of Si-C electrode with low carbon content might be easier than the case with high carbon content. The electronic conduction pathway of Si-C electrode will be degraded, caused by the volume expansion of silicone during the long lasting chargedischarge. An increase of the IIE value with an increase of PAn precursor contents in Si-C materials was achieved by an improvement of the electronic conduction pathway. SiC(Si:PAn $=70: 30$ wt. ratio) $[\mathrm{Li}$ cells with PAn precursor, excluding $\mathrm{HCl}$ dopant and the electrolyte without $\mathrm{FEC}$ additive, showed the range of reversible capacity of 169 $\mathrm{mAh} / \mathrm{g}$, the IIE of $70.9 \%$, and IICs of $11.3 \mathrm{mAh} / \mathrm{g}$. And the cell with FEC additive showed the range of reversible

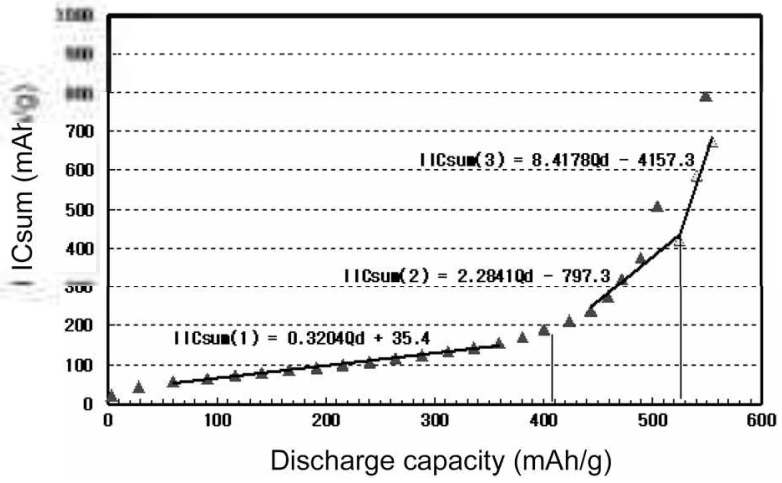

Figure 7. The accumulated irreversible capacity of $\mathrm{Si}-\mathrm{C}(\mathrm{Si}: \mathrm{PAn}$ $(50.50 \mathrm{wt}$.ratio) $) \mathrm{Li}$ cell against discharge capacity. 
Table 1. GISOC Characteristics of Si-C|Li Cells

\begin{tabular}{|c|c|c|c|c|c|c|c|}
\hline $\begin{array}{l}\text { PAn content in } \\
\text { Si-PAn } \\
\text { composite for } \\
\text { Si-C (wt. \%) }\end{array}$ & Electrolyte & $\begin{array}{c}\text { HCl Doped } \\
\& \\
\text { Undoped }\end{array}$ & $\begin{array}{c}\text { The 1st } \\
\text { reversible specific } \\
\text { capacity range } \\
(\mathrm{mAh} / \mathrm{g})\end{array}$ & $\begin{array}{l}\text { The 1st initial } \\
\text { intercalation } \\
\text { eefficiency } \\
\text { (IJE. \%) }\end{array}$ & $\begin{array}{l}\text { The 1st initial } \\
\text { itreversible } \\
\text { specific capacity } \\
\text { (IICs, mAh/g) }\end{array}$ & $\begin{array}{l}\text { The } 2 \text { nd } \\
\text { reversible specific } \\
\text { capacity range } \\
(\mathrm{mAh} / \mathrm{g})\end{array}$ & $\begin{array}{l}\text { The } 2 \text { nd initial } \\
\text { intercalation } \\
\text { efficiency } \\
\text { (JJE, \%) }\end{array}$ \\
\hline 0 & [E] & - & 49 & 27.8 & 49.3 & 50 & 0.71 \\
\hline 30 & [E] & Doped & 150 & 55.1 & 46.6 & 160 & - \\
\hline 30 & [E] & Undoped & 168 & 70.9 & 11.3 & 189 & 4.58 \\
\hline 50 & [E] & Doped & 414 & 75.7 & 35.4 & 527 & 30.4 \\
\hline 0 & [E] with FEC & - & 50 & 25.5 & 276.2 & - & - \\
\hline 30 & [E] with FEC & Doped & 194 & 71.4 & 30.2 & 200 & - \\
\hline 30 & [E] with FEC & Undoped & 187 & 66.7 & 3.8 & - & - \\
\hline 50 & [E] with FEC & Doped & 330 & 73.8 & 38.2 & 394 & 9.8 \\
\hline
\end{tabular}

[E]: 1 M LiPF6/EC:EMC:DMC:PC (4:3:3:1)

capacity of $195 \mathrm{mAh} / \mathrm{g}$ and the IIE of $71.4 \%$, and IICs of $30.2 \mathrm{mAh} / \mathrm{g}$.

\section{Conclusion}

Modified Si-C materials were prepared by Si powder and polyaniline (PAn), and their physical and electrochemical properties were characterized. $\mathrm{Si}-\mathrm{C}$ materials from the carbonization of Si-PAn, which was obtained by the oxidative polymerization of aniline to coat Si particles, showed the coexistence of low crystalline carbon. Carbon covering of $\mathrm{Si}$ particle was efficient for high PAn content. The better electrochemical perfonmances were confirmed for Si-C materials compared with that of Si materials by cycling and GISOC tests.

Some differences in electrochemical performance was observed between doped and undoped PAn. PAn precursors not doped with $\mathrm{HCl}$ showed better results than $\mathrm{HCl}$-doped PAn precursors. TGA-DSC analyses showed the initial evaporation of one $\mathrm{HCl}$ and three $\mathrm{H}_{2} \mathrm{O}$ per $\mathrm{PAn}$ unit formula. The cell with the electrolyte-including FEC additive showed a high initial discharge capacity compared with that without the FEC additive. The $\mathrm{Si}-\mathrm{C}(\mathrm{Si}: \mathrm{PAn}=50: 50$ wt. ratio $) \mid \mathrm{Li}$ cell showed a range of reversible capacity of $c a .414 \mathrm{mAh} / \mathrm{g}$, the IIE of $75.7 \%$ and the IICs of $35 \mathrm{mAh} / \mathrm{g}$.

\section{References}

I. Berthier, C.; Gorecki, W.; Minier, M.; Armand, M. B.; Chabagno, J. M.; Rigaud, P. Solid State lonics 1983, 1, 91-95.

2. Ratner, M. A.; Shriver, D. F. Chemical Reviews 1988, 88, $109-$ 124.

3. Ballard, D. G H.; Cheshire, P.; Mann, T. S.; Przeworski, J. E. Macromolecules 1990, 23, 1256-1264.

4. Jin, B. S.; Doh, C. H.; Moon, S. I.; Yun, M. S.; Jeong, J. K.; Nam, H. D.; Park, H. G. J. of Korean Electrochenical Society 2004, 7, [43-147.

5. Kim, W. S.; Park, D. W.; Jung. H. J.; Choi, Y. K. Bull. Korean Chem, Soc. 2006, 27, 82-86.

6. Poizot, P.; Larulle, S.; Grugeon, S.; Dupont, L.; Tarascon, J. M. Nature 2000, 407, 496-499.

7. Wang, G. X.; Chen, Y.; Konstantinov, K.; Lindsay, M.; Liu, H. K.; Dou, S. X. J. of Power Sotreses 2002, 100, 142-147.

8. Doh, C. H.; Kalaiselvi, N.; Park, C. W.; Jin, B. S.; Moon, S. I.; Yun, M. S. Electrochemistry Commuications 2004, 6, 965-968.

9. Beaulieu, L. Y.; Beattie, S. D.; Hatchard, T. D.; Dahn, J. R. J. Electrochemical Society 2003, 150, A4 19-A424.

10. Doh. C. H.; Jin, B. S.; Park, C. W. Moon, S. I.; Yun, M. S. J. of KIEE 2003, 3-C, 189-193.

I1. Doh, C. H.; Park, C. W.; Jin, B. S.; Moon, S. I.; Yun, M. S. J. of KIEE 2004, 4-C, 21-25.

12. Doh, C. H.; Kim, H. S.; Moon, S. I. J. of Power Soures 2001, 101,96-102.

13. Kihoshita, K. CARBON; John Wiley \& Sons: New York, U.S.A. 1988. 